\title{
Psychological characteristics of mothers of patients with anorexia nervosa: implications for treatment and prognosis
}

\author{
Características psicológicas de mães de pacientes com anorexia nervosa: \\ implicações para o tratamento e prognóstico
}

Lia Keuchguerian Silveira Campos, ${ }^{1}$ Anna Beatriz Ribeiro Ferreira Sampaio, ${ }^{2}$ Celso Garcia Junior, ${ }^{3}$

Ronis Magdaleno Junior, ${ }^{4}$ Maria Marta de Magalhães Battistoni, ${ }^{5}$ Egberto Ribeiro Turato ${ }^{6}$

\begin{abstract}
Introduction: The complexity of factors involved in anorexia nervosa (AN) and the recommendations of prominent health organizations underscore the importance of reflecting on therapeutic interventions aimed at patients' family members.

Objective: To expand knowledge about the mother-daughter relationship in AN, with a focus on developing a conceptual framework that is able to improve the treatment of the disorder, reduce factors that perpetuate it and improve prognosis.

Method: A clinical method, anchored by psychodynamic references, was employed in a group of family members of patients with eating disorders. The group met weekly, and sessions were led by psychologists from the eating disorder outpatient clinic of a university hospital.

Results and Discussion: Common characteristics in the mother-daughter relationship in cases of AN were identified. The issue of mutual control, the dialectic between omnipotence and impotence, and the relationship of devotion, passion and annihilation between mothers and daughters are phenomena that form the basis of AN, with a direct influence on the severity of each case and on treatment success.

Conclusion: Our findings allowed us to identify important aspects in the mother-daughter relationship in AN, which may improve the clinical interventions aimed at treating the disorder. Keywords: Anorexia nervosa, mother-child relations, qualitative research.
\end{abstract}

\section{Resumo}

Introdução: A complexidade de fatores que compõem a anorexia nervosa (AN) e as recomendações de importantes organizações ligadas à saúde torna fundamental uma reflexão acerca de propostas de intervenções psicoterapêuticas direcionadas aos familiares desses pacientes.

Objetivo: Expandir o conhecimento acerca da relação mãefilha na AN, visando desenvolver uma estrutura conceitual que aperfeiçoe o tratamento do transtorno, reduza os fatores que 0 mantêm e melhore o prognóstico.

Método: Utilizou-se um método clínico de observação fundamentado em referenciais psicodinâmicos de um grupo de familiares de pacientes com transtornos alimentares. O grupo aberto, semanal, era coordenado por psicólogas do ambulatório de transtornos alimentares de um hospital universitário.

Resultados e Discussão: Foram identificadas características comuns da relação mãe-filha nos casos de AN. A questão do controle mútuo, a dialética entre onipotência e impotência e a relação de devoção, paixão e aniquilamento entre mães e filhas são fenômenos que estão na base da estrutura da AN, com influência direta sobre a gravidade de cada caso e sobre o sucesso das possibilidades terapêuticas.

Conclusão: Os achados possibilitaram identificar importantes aspectos da relação mãe-filha na AN, que podem aprimorar as intervenções clínicas para seu tratamento.

Descritores: Anorexia nervosa, relações mãe-filho, pesquisa qualitativa.

\footnotetext{
1 Psicóloga. Mestranda em Ciências Médicas, Faculdade de Ciências Médicas, Universidade Estadual de Campinas (UNICAMP), Campinas, SP, Brazil. Bolsista, Conselho Nacional de Desenvolvimento Científico e Tecnológico (CNPq). ${ }^{2}$ Psicóloga. Mestranda em Ciências Médicas, Faculdade de Ciências Médicas, UNICAMP. ${ }^{3}$ Psiquiatra. Coordenador, Ambulatório de Transtornos Alimentares, Hospital de Clínicas, UNICAMP. Doutorando em Saúde Mental, Faculdade de Ciências Médicas, UNICAMP. ${ }^{4}$ Psiquiatra. Doutor em Ciências Médicas. Pesquisador colaborador, Laboratório de Pesquisa Clínico-Qualitativa, Faculdade de Ciências Médicas, UNICAMP. Membro associado, Sociedade Brasileira de Psicanálise de São Paulo. ${ }^{5}$ Psicóloga. Doutora. Professora, Departamento de Psicologia Médica e Psiquiatria, Faculdade de Ciências Médicas, UNICAMP. ${ }^{6}$ Psiquiatra. Professor livre-docente, Faculdade de Ciências Médicas, UNICAMP. Coordenador, Laboratório de Pesquisa Clínico-Qualitativa, Departamento de Psicologia Médica e Psiquiatria, Faculdade de Ciências Médicas, UNICAMP.

This paper is part of the acculturation phase of the first author's Master's program. The research project has been presented and approved without restrictions by the Ethics Committee of Faculdade de Ciências Médicas of UNICAMP on May 112009 (protocol no. 423/2009, CAAE: 0335.0.146.000-09).

This paper was presented as a poster at the IV Semana da Pesquisa da FCM/UNICAMP, at Faculdade de Ciências Médicas of UNICAMP, held in São Paulo, Brazil, in May 2010, and at the 19th European Congress of Psychiatry, held in Vienna, Austria, in March 2011.

Submitted Aug 31 2011, accepted for publication Oct 26 2011. No conflicts of interest declared concerning the publication of this article.

Suggested citation: Campos LK, Sampaio AB, Garcia Jr C, Magdaleno Jr R, Battistoni MM, Turato ER. Psychological characteristics of mothers of patients with anorexia nervosa: implications for treatment and prognosis. Trends Psychiatry Psychother. 2012;34(1):13-8.
} 


\section{Introduction}

Anorexia nervosa (AN) is an eating disorder characterized by an overvaluation of weight and body shape, with an extreme weight control behavior. ${ }^{1}$ Biological, social and psychological factors are involved. ${ }^{1}$ There is a major sex difference in the incidence of eating disorders ${ }^{2,3}: 90 \%$ of the cases of AN are diagnosed in women. ${ }^{1}$

The 2004 Eating Disorder Guide published by the National Institute for Clinical Excellence (NICE) points to the scarcity of information available to guide health care workers in the treatment of AN. The guide emphasizes that pharmacological treatment alone is not recommended and advocates individual and family therapy focused on eating disorders as an essential part of the therapy. ${ }^{4}$

The psychic dynamic of AN is essentially feminine; its core elements are eating, the body, sexuality and the mother-daughter relationship. ${ }^{5}$ From a psychodynamic point of view, females with AN express today the symptoms of ancient pathologies, incorporating in their bodies, in an original, singular and modern way, histories of lives jeopardized through several generations. ${ }^{5}$

The mothers of patients with AN are women whose femininity has been devalued, who offer a very poor identification model, like a negative of an ideal. This can lead the daughter to resort to AN as a means to erase all traces of femininity from their bodies. ${ }^{6}$

Lawrence $^{7}$ points to the impasse between desire and the fear of fusion with the mother in girls with AN. The main fantasy of the anorexic patient is that, by rigidly controlling food intake, she will also control her internal parents and their relationship. By impeding the relationship of the internal parents, the oedipal configuration becomes impossible, and the building of a space for symbolization fails. ${ }^{7}$

A common problem in patients with AN is the invasive desire of the mother, which imposes itself and takes possession of the daughter's body and desire. ${ }^{8} \mathrm{~A}$ lovehate struggle is initiated, to which mother and daughter are confined and in which they are fused. ${ }^{8}$

As a result of this dynamic, many caregivers, especially mothers, express deep anxiety, which can become clinically severe, with negativist concerns, hostility, criticism, and an over-protective attitude towards the daughter. ${ }^{9}$ This emotional response has been described as an exacerbated emotional expression, ${ }^{10}$ and has a negative impact on the prognosis of AN.

Taking into consideration the characteristics of family dynamic, family involvement in the treatment of eating disorders has been advocated.1,11-14 Family therapy, when started at the onset of the disorder, achieves greater efficacy when compared with other therapeutic approaches. ${ }^{15}$

The initial reaction of parents - shock, disbelief, confusion, anger, conflict, and tension - can lead to a distorted perception of the illness, underestimating the problem and denying diagnosis. Such a distorted perception can determine the decision to seek (or not to seek) professional help. ${ }^{16}$

Among the emotional states identified in the parents of patients with AN, the most recurrent one is impotence, i.e., the perception that any action taken by parents will barely affect treatment results. ${ }^{9,16}$ Parents feel manipulated and controlled, the core life experiences in the dynamic of AN.9,17 They are fusional families, with overprotective traits, an urge to control and great difficulty dealing with the separation and independence of family members. ${ }^{16}$

Taking this framework into consideration, the current trend is to propose an integrated treatment approach, in which weight gain, a better psychiatric picture and therapeutic interventions aimed at the psychological characteristics of individuals and of the family as a whole have the same weight and importance. ${ }^{18}$

This study aimed to extend knowledge about the main psychological characteristics of mothers of daughters with AN, especially with regard to their relationship with their daughters, with a focus on developing a conceptual framework for interventions that is able to improve the treatment of the disorder, reduce the factors that perpetuate it, and improve prognosis.

\section{Method}

The present study is the result of clinical-psychological reflections emerging from the first author's acculturation process $^{19}$ in this field of research. The study is part of the first author's Master's project, currently in progress, which will assess mothers of AN patients at the Outpatient Clinic for Eating Disorders of the university hospital of Universidade Estadual de Campinas (UNICAMP), state of São Paulo, Brazil.

We adopted a clinical method, in an attempt to understand the problems emerging from observation and clinical practice. Also, we used an interpretative model commonly used in social sciences, in which we first understand, then connect senses and finally organize the knowledge acquired. ${ }^{20}$ This method allows to qualitatively analyze the data collected; this procedure is a scientific research tool and helps validate the results obtained. ${ }^{21}$

This article contains reflections arising from the clinical observation of an open therapy group during the psychological treatment of mothers of patients with AN at the general hospital of UNICAMP. The group comprised seven participants. Meetings were held weekly, led by psychologists of the eating disorders outpatient clinic. Participation of patients' family members was voluntary. The clinical material used to illustrate the emotional 
movement of participants was obtained from verbatim notes taken by the investigator (L.K.S.C), who attended the group as an observer for 1 year.

Analysis of the material arising spontaneously during the group sessions, of what we were able to understand from the group dynamic, and of discussions with peers at the clinic and laboratory allowed us to identify some phenomena that constitute the psychic reality of mothers of patients with AN, and of their dynamic in the family.

The study was developed in conformity with applicable ethical guidelines, and the research project was approved by the Ethics Committee of the School of Medical Sciences of UNICAMP (protocol no. 423/2009). Group participants were informed of the objectives of the study and were asked to sign an informed consent form. Participants were informed that the material collected would be kept anonymous but could be used in future research and publications. All patients agreed to sign the form.

\section{Results and discussion}

Based on clinical observations and psychodynamic references, we were able to identify common traits of the mother-daughter relationship in the specific case of AN. We distinguished some categories, which have been briefly presented before ${ }^{22}$ and which we intend to discuss in greater depth below, e.g. the issue of mutual control, the dialectic between omnipotence and impotence, and the relation of devotion, passion and hostility between mothers and daughters. We believe that these phenomena form the basis of the external and internal structures of patients with $\mathrm{AN}$, with direct influence on the severity of each case and on treatment success.

\section{The issue of mutual control}

The problem of control is at the core of the psychological dynamic in patients with AN and in their relations with the family and the environment. ${ }^{9}$ The incidence of obsessive-compulsive disorder ${ }^{2}$ is high in the families of these patients, with evidence suggesting that the two disorders have risk factors in common. ${ }^{23}$ In addition, perfectionism and inflexibility are personality traits frequently found in relatives of patients with AN. ${ }^{23,24}$

We believe that the psychological dynamic of the personality traits mentioned above is closely related to control. A continuous tension between impulses and the need to control them is expressed as a constant struggle between mothers and their daughters.

Now with this illness, I have to wait a bit before shaping her head again.
We have to be smarter than them, otherwise they dominate us.

Mothers show a need to control their daughters, arguing that they do not believe the daughters are able to look after themselves. They deny their individuality and try to be the tutors of their daughters' acts. However, as they impose this control pattern, they are paradoxically confined and controlled by their daughters, creating a vicious circle of mutual distrust and invasion of privacy.

I'm the one who tells her she has to eat.

Honey \& Halse ${ }^{25}$ emphasize that family members are involved in exploring, in several ways, the lives of their daughters, in an attempt to understand their behavior, identify possible means of foreseeing their reactions and learn from their experiences. We understand that this attempt to monitor their daughters is directly related to their need to keep their daughters under control. However, as they invest all their energy into this attitude, they end up also being controlled by their daughters. Confined to this cycle of mutual control, the mothers become even more ignorant of the individuality and intimacy of their daughters.

One day she told me 'I want to be myself...' But she is no longer herself...

After several attempts at mutual control, a movement that ends in indifferentiation, with loss of psychic and emotional borders, is established between mother and daughter. What belongs to the mother and what belongs to the daughter is no longer distinguishable.

She sticks to me... seems to be my shadow.

It's symbiosis... they control us.

By using strategies to escape the control that caregivers try to impose, AN patients end up completely dominating the family routine, as well as the mental space of each family member, directing all care and concerns towards themselves.

This group is the only space for us because outside we have no space: it's all for them.

The mothers feel that, in a way, their daughters use anorexia as a strategy to control their lives and the lives of others. As Viglietti ${ }^{6}$ points out, it is possible to think of these mothers as women who are rigidly bound to submitting themselves to the demands of the daughters. Moreover, they are predisposed to a sadomasochistic 
relationship with their daughters, and thus they are unable to understand the suffering that underlies the symptoms and their own difficulties as mothers.

They are cruel and enslave us.

The feeling of distrust is highly prevalent in family relations, creating a vicious circle of lies, contradictions, investigation and collusion, which increasingly hinders any genuine attempt to get closer to the mental world marked by the suffering of this girl who is dying both physically and mentally.

I don't trust her, I don't think she is able to choose.

Relationships become permeated with guilt. Mothers can keep the illusion of power and protection, without realizing that they are deeply involved and paralyzed by their daughters' illness (or, to be more precise, by the illness marking the relationship between mothers and daughters).

The doctor said that she should drink less calorific milk, but I mix one that has more nutrients than the one the doctor recommended.

The medical staff should be alert, because the same need to control family relations may be transferred to the medical staff. The latter may then be invited, or even forced, to join this complex game of control and loss of individuality.

You have to reach an agreement among yourselves not to use the words normal, fat, better, because this bothers them... I'm going to talk to the doctor about this.

\section{The dialectic between omnipotence and impotence}

Impotence is the overriding feeling of these mothers, who fail in their numerous attempts to help/control their daughters. The feeling of impotence is accompanied by intense feelings of guilt, as if they were responsible for their daughters' disorder.

I feel guilty because I made her promise that she wouldn't vomit any more, but then she stopped eating (starts to cry).

The impasse revealed in this mother's words clearly circumscribes the game established between the mother and the daughter, a standoff in which the perpetuation of illness is inevitable. In our view, there is a collusion that cannot be broken by the pair, tied to a pact whose final objective is to maintain psychic fusion.
There is a frequent omnipotent fantasy that mothers can change the world around their daughters so as to help them.

I have spoken to her sisters and friends and mainly with her father so that they don't keep talking about people's physical appearance, about weight, but it's no good.

When mothers realize that they cannot change the world, they experience a strong feeling of impotence, with periods of anguish, which in turn reinforces their need to control. In this sense, mothers create an illusion that they can guess what the daughters are thinking, which reveals a belief in the fusion between the daughter's and their own psyche.

These mothers believe to be the ones who know their daughters best; as such, they believe they are the ones most able to help their daughters. Conversely, they fail to realize that it is precisely the fact of being mothers that distances them from their daughters as autonomous individuals, making it impossible for mothers to give their daughters the help they so badly need.

Sometimes she is all smiles and then I appear and she changes... Am I that disturbing?

According to Gorgati, ${ }^{18}$ the alliance and struggle formed between mother and daughter cordon them off from the rest of the world; in this scenario, the father is seen as an intruder who disturbs the fused mother/ daughter. We have observed that the mother tries to collude with the daughter against the father, arguing that mother and daughter need each other in order to deal with a not very understanding father.

\section{A husband is the worst possible thing in the world.}

There is disparagement of husbands who do not help with household chores, who are dependent on mothers and who fail to help care for their daughter. In an omnipotent attitude, this movement seeks to maintain the fusional relationship between the mother and the daughter, at the cost of annulling the father as an important figure in the family dynamic.

It's only me, you see! I'm struggling alone against this disease, just me... Oh, and her, of course.

\section{Devotion, passion and annihilation}

The passionate devotion that these mothers dedicate to their daughters hides the central aspect of these relationships: the annihilation of the other as an 
individual being. The daughter ceases to exist as an individual, is in some way destroyed as such.

I do everything for her... I have slept with her in the same bed and with the door closed and the key in my pocket.

She gets a tummy ache and I even go to the bathroom with her.

We believe that the potentially fatal reaction expressed through anorexic behaviors is motivated by the mother's invitation to annihilate the daughter's individuality. However, the established collusion is doubly dangerous, for mother and daughter, once the final result of this process of dependency and control is that both lose their identity and autonomy in relation to life and creativity.

As argued above, the mother's desire is imposed and takes over the daughter's body and desire, ${ }^{8}$ at the cost of her individual freedom. A fusional state between mother and daughter arises, ${ }^{7}$ with the mother becoming even more limited in the task of understanding the daughter's real needs, and the daughter becoming a part of the mother that dares to function beyond her control.

When she goes out alone, it seems a piece of me leaves... I become anguished as if I had a piece missing.

The final result of this whole process is an emptying of feelings and an impoverishment of internal representations. The lives of mother and daughter are reduced to a state of passion and devotion that polarizes all their possibilities.

She seems to be a hollow 'jatobá' [a luxuriant Brazilian tree]. (said by a father)

\section{Conclusion}

Given the complexity of factors involved in the clinical picture of $\mathrm{AN}$ and the recommendations of prominent health organizations, it becomes extremely important to reflect on the different therapeutic approaches available for the family members of these patients.
The aim of this study was to develop a conceptual framework for therapeutic interventions that is able to improve the way caregivers deal with the disorder and to reduce the factors that affect prognosis and prolong the disorder. The data collected from the speech of relatives of patients with eating disorders led to reflections on important aspects of the psychic dynamic underlying the pathology. By analyzing the experience of mothers who look after daughters with AN, we were able to identify important aspects that can improve clinical interventions in the treatment of AN (Table 1).

We have identified frequent characteristics among mothers of AN patients, which configure a very particular psychic structure and influence the daughters' pathology. Among such characteristics, we emphasize the issue of mutual control, the dialectic between omnipotence and impotence, and the presence of feelings of devotion, passion and annihilation. These aspects can only be properly addressed and treated by professionals who understand the psychic dynamic of this group of patients and of their family and social environment.

Widely present in the scientific literature, the psychotherapeutic treatment of mothers is fundamentally important for the daughters' treatment. We have endeavored to expand knowledge in this particular field with the aim of providing the multidisciplinary team with better tools to deal not only with the patient with the disorder, but also with their family members, so as to broaden the understanding of issues involved in eating disorders.

The team should be alert and well-informed, once the same characteristics identified in the mother-daughter relationship can easily be transferred to the clinical setting. Such transfer could lead to misunderstandings between the team and the patients/caregivers, especially when dealing with the issue of control, the experience of impotence, and feelings of hostility and invasion. This, in turn, could lead the health team to adopt anti-therapeutic attitudes, of rejection or over-protection towards the patients, which in no way would help established the therapeutic alliance or achieve a good prognosis.

We agree with Viglietti ${ }^{6}$ in that what makes the family approach indispensable is the need to quickly disarticulate

Table 1 - Recommendations to deal with anorexia nervosa

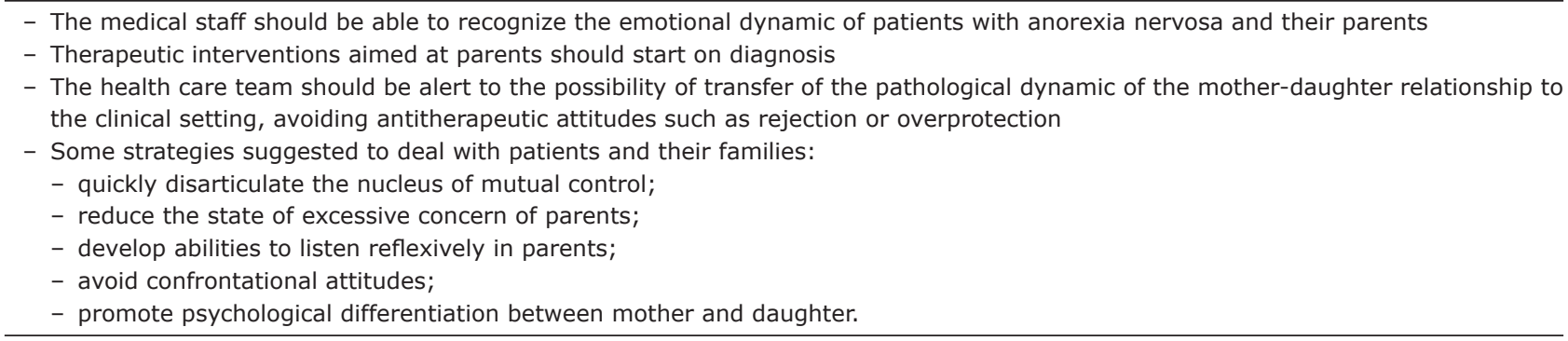


the nucleus of mutual control, which conceals distrust and the absence of empathy. Such control regulates the relationship between AN patients and their families and keeps them imprisoned in a rigidly consolidated dynamic, whose main purpose is to prolong symptoms. We understand that under the disguise of an attitude of passionate devotion lies the psychic annihilation of the other -in extreme cases, this really can lead to the physical death of the patient with AN.

The assistance provided to patients should include sessions with family members from the time of diagnosis until the end of the proposed intervention, with a focus on addressing the demands of family members, providing explanations and general information on the disorder, and dealing with situations involved in the complex psychological structure of patients and their families. We agree with Whitney et al. ${ }^{9}$ when they state that the team should be trained for family work, including strategies to reduce the excessive concern of caregivers, to help them develop the ability to listen reflexively, so as to decrease confrontational attitudes, and to encourage them to seek psychological support and to accept respite whenever necessary. The topics related to exacerbated emotional expression ${ }^{10}$ (overprotection, critical attitude, and hostility) should be identified and avoided both by the family and the by the medical staff, once they impair prognosis in cases of AN. Only a health team that is trained to recognize the emotional dynamic of this group of patients will be able to work effectively for an adequate therapeutic intervention within the multidisciplinary treatment team.

The experience here reported with mothers of AN patients reassures the complex role of the motherdaughter relationship in the development of the disorder and allows us to suggest some guidelines to the work of multidisciplinary teams. We are aware that we are only shedding some light on the difficult topic we chose to study. Nevertheless, we hope that the present findings will serve as a stimulus to new research aimed at expanding this important area of health, which has serious consequences for AN patients and their families.

\section{References}

1. Fairburn CG, Harrison PJ. Eating disorders. Lancet. 2003; 361:407-16

2. American Psychiatric Association. Diagnostic and Statistical Manual of Mental Disorders, 4th edition (DSM-IV). Washington: APA; 1994.

3. World Health Organization, Department of Gender, Women and Health, Family and community health. Gender in mental health research. Geneva: WHO; 2005. www.who.int/gender/ documents/MentalHealthlast2.pdf. Accessed 27 Aug 2010.

4. Wilson GT, Shafran R. Eating disorder guidelines from NICE. Lancet. 2005; 365:79-81.

5. Miranda RM. O mundo objetal anoréxico e a violência bulímica em meninas adolescentes. Rev Bras Psicanal. 2004;38:309-34.

6. Viglietti GV. Os pais na anorexia nervosa: uma abordagem psicanalítica. Rev Bras Psicanal. 2001;35:97-106.
7. Lawrence M. Loving them to death: the anorexic and her objects. Int J Psycho-Anal. 2001;82:43-55.

8. Camargo I. Anorexia e bulimia: o negativo do corpo - um colar de pérolas sem fio. In: Bucaretchi HA. Anorexia e bulimia nervosa: uma visão multidisciplinar. São Paulo: Casa do Psicólogo; 2003. p. 111-23.

9. Whitney J, Murray J, Gavan K, Todd G, Whitaker W, Treasure J. Experience of caring for someone with anorexia nervosa: qualitative study. Br J Psychiatry. 2005;187:444-9.

10. Wearden AJ, Tarrier N, Barrowclough C, Zastowny TR, Rahill AA. A review of expressed emotion research in health care. Clin Psychol Rev. 2000;20:633-66.

11. Couturier J, Isserlin L, Lock J. Family-based treatment for adolescents with anorexia nervosa: a dissemination study. Eat Disord. 2010;18:199-209.

12. Cobelo AW, Saikali MO, Schomer EZ. A abordagem familiar no tratamento da anorexia e da bulimia nervosa. Rev Psiq Clin. 2004;31:184-7.

13. Pinzon V, Gonzaga AP, Cobelo A, Labaddia E, Belluzzo $P$, Fleitlich-Bilyk B. Peculiaridades do tratamento da anorexia e da bulimia nervosa na adolescência: experiência do PROTAD. Rev Psiq Clin. 2004;31:167-9.

14. Jaeger MAS, Seminotti N, Falceto OG. O grupo multifamiliar como recurso no tratamento dos transtornos alimentares. Rev Psiquiatr Rio Gd Sul. 2011;33:20-7.

15. Kaplan AS. Psychological treatments for anorexia nervosa: a review of published studies and promising new directions. Can J Psychiatry. 2002;47:235-42.

16. Espíndola CR, Blay SL. Percepção de familiares sobre a anorexia e bulimia: revisão sistemática. Rev Saude Publica. 2009;43:707-16.

17. Tan JO, Hope T, Stewart A, Fitzpatrick R. Control and compulsory treatment in anorexia nervosa: the views of patients and parents. Int J Law Psychiatry. 2003;26:627-45.

18. Gorgati SB. O feminino congelado na anorexia. In: Alonso SL, Gurfinkel AC, Breyton DM, editors. Figuras clínicas do feminino no mal-estar contemporâneo. São Paulo: Escuta; 2002.

19. Turato ER. Tratado da metodologia da pesquisa clínicoqualitativa. Construção teórico-epistemológica, discussão comparada e aplicação nas áreas da saúde e humanas. 5th ed. Petrópolis: Vozes; 2011.

20. Arruda SLS. Vivências clínicas de um grupo de mães cujos filhos estão em ludoterapia [thesis]. Campinas: Universidade Estadual de Campinas; 1991.

21. Calil SCC, Arruda SLS. Discussão da pesquisa qualitativa com ênfase no método clínico. In: Grubits S, Noriega JAV, editors. Método qualitativo: epistemologia, complementariedades e campos de aplicação. São Paulo: Vetor; 2004. p. 173-213.

22. Campos LK, Sampaio AB, Garcia C, Magdaleno R, Battistoni MM, Turato ER. Psychological characteristics of anorexic patients' mothers in the Southeast Brazil: Implications for treatment and prognosis of anorexia nervosa in a public service. Proceedings of the 19th European Congress of Psychiatry. Eur Psychiatry. 2011;26:735.

23. Lilenfeld LR, Kaye WH, Greeno CG, Merikangas KR, Plotnicoy K, Pollice C, et al. A controlled family study of anorexia nervosa and bulimia nervosa: psychiatric disorders in firstdegree relatives and effects of proband comorbidity. Arch Gen Psychiatry. 1998;55:603-10.

24. Woodside DB, Bulik CM, Halmi KA, Fichter M, Kaplan A, Berrettini $\mathrm{WH}$, et al. Personality, perfectionism, and attitudes toward eating in parents of individuals with eating disorders. Int J Eat Disord. 2002;31:290-9.

25. Honey A, Halse $C$. The specifics of coping: parents of daughters with anorexia nervosa. Qual Health Res. 2006;16:611-29.

\section{Correspondence:}

Lia Keuchguerian Silveira Campos

Rua Padre Almeida, 565 cj. 11, Cambuí

13025-251 - Campinas, SP - Brazil

Tel.: +55 (19) 3255.0691

E-mail: liacampos81@uol.com.br 